\title{
Does Mentoring Women Matter, and if so, How Much?
}

\section{¿Importa la mentoría a las mujeres y, de ser así, cuánto?}

\author{
Catalina Solano ${ }^{1}$ Rena D. Malik ${ }^{2}$ \\ ${ }^{1}$ Uroclin, Medellín, Colombia \\ 2 Division of Urology, Department of Surgery, University of Maryland \\ School of Medicine, Baltimore, Maryland, United States
}

Urol Colomb 2020;29:245-246.

\begin{abstract}
Address for correspondence Catalina Solano, Uroclin, Medellín, Colombia (e-mail: catasolano84@gmail.com).
\end{abstract}

The presence of women in medicine and urology has been increasing. However, there is a large disparity in leadership positions. In 2017 , women constituted $3.3 \%$ of chairs, $4.5 \%$ of vice-chairs, and $7.9 \%$ of division directors in the United States, ${ }^{1}$ similar positions in Colombia. It is unclear why this deep gender gap exists in urology. Multifactorial and specialty-specific factors may include lack of mentorship, sponsorship, and limited female role models in leadership positions. ${ }^{2}$ According to the Association of Medical Colleges (AAMC), many women do not find mentors in surgical specialties. This lack of mentorship may limit women from accessing similar opportunities to their male counterparts. ${ }^{3}$

In male-predominant medical specialties, women face other obstacles; among these, the challenges in balancing work and personal life, gender stereotypes, and bias. In these aspects, mentorship, particularly from individuals who understand gender-specific challenges, is eminent to achieve professional career growth. ${ }^{4}$ A mentor imparts knowledge, gives support, and guides mentees to achieve their goals, improved adjustment, positive career attitudes, and intervenes in non-academic subjects like navigating interpersonal relationships, preparing for career success in promotion, research, and clinical arenas. ${ }^{5,6}$ Additionally, mentorship is linked to improving self-rated wellbeing, self-esteem, and self-efficacy, also significant improvements in writing, networking, critical appraisal, and other skills. These competencies facilitate women's access to leadership positions and professional progress in surgical specialties. ${ }^{7}$ In urologic history, Mary Childs MacGregor, the world's first female urologist, contributed to women's scholarships in subspecialties and was a mentor for Elisabeth Pauline Pickett. The latter subsequently became the first certified female urologist.

Nonetheless, mentorship is not enough for women's career advancement; it is necessary to have a sponsor. A sponsor is an individual who advises the mentee and advocates for career advancement and is typically a leader in the organization with resources and access to the network and critical contacts. This person allows him/her to support the career of a "protégé" earnestly. Despite the existent differences between mentorship and sponsorship, mentoring is a dyadic relationship that stands through time. Sponsoring is generally episodic and centered on specific opportunities; both relationships are essential to professional development. ${ }^{8}$

However, challenges exist in finding mentors, female role models, and sponsors. Forming communities that promote more significant opportunities for women is essential. It plays a fundamental role in increasing visibility, offering networking opportunities, and subsequent promotion to leadership positions. Examples of these communities include the Society of Women In Urology (SWIU), the American Medical Women's Association (AMWA), and the Colombian Group of Women in Urology. These organizations allow the amplification and support of women and offer opportunities to promote women in the public arena.

To continue attracting and retaining women in urology, we need to continue to improve mentorship opportunities available to them. We suggest training institutions consider offering faculty development programs in mentorship and sponsorship, including discussing issues specific to women. Additionally, supporting women in leadership development opportunities and gender-specific meetings such as the Society of Women in Urology is strongly encouraged. On an individual level, discussing with female faculty and trainees about their goals and career development plans to identify specific areas for improvement and support can be significantly valuable in creating future female leaders in the field.

\section{References}

1 Han J, Stillings S, Hamann H, Terry R, Moy L. Gender and Subspecialty of Urology Faculty in Department-based Leadership Roles. Urology 2017;110:36-39
DOI https://doi.org/ 10.1055/s-0040-1721332. ISSN 0120-789X. e ISSN 2027-0119.
Copyright @ 2020, Thieme Revinter Publicações Ltda.., Rua do Matoso 170, Rio de Janeiro, RJ, CEP 20270-135, Brazil. Todos los derechos reservados.

\section{uneretertum \\ $\otimes(1) \ominus \circledast$}


2 Chyu J, Peters CE, Nicholson TM, et al. Women in Leadership in Urology: The Case for Increasing Diversity and Equity. Urology 2020:S0090-4295(20)31112-2

3 Miller RS, Dunn MR, Richter T. Graduate medical education, 19981999: a closer look. JAMA 1999;282(09):855-860

4 Strong EA, De Castro R, Sambuco D, et al. Work-life balance in academic medicine: narratives of physician-researchers and their mentors. J Gen Intern Med 2013;28(12):1596-1603

5 Austin AE. Preparing the Next Generation of Faculty. J High Educ (Columb Ohio) 2002;73(01):94-122
6 Gómez-Ospina JC, García-Perdomo HA. Mentoring: A revolutionary act. Int J Surg 2019;65:94-95

7 Walsh MR. Doctors Wanted: No Women Need Apply: Sexual Barriers in the Medical Profession, 1835-1975 [Internet]. eweb:17971 1977 [citado 24 de octubre de 2020]. Disponible en: https://repository.library.georgetown.edu/handle/10822/775336

8 Ayyala MS, Skarupski K, Bodurtha JN, et al. Mentorship Is Not Enough: Exploring Sponsorship and Its Role in Career Advancement in Academic Medicine. Acad Med 2019;94(01):94-100 